\title{
Allogeneic Large Multivalent Immunogen Breast Cancer Vaccine
}

National Cancer Institute

\section{Source}

National Cancer Institute. Allogeneic Large Multivalent Immunogen Breast Cancer

Vaccine. NCI Thesaurus. Code C79799.

A cancer vaccine, containing human-specific large multivalent immunogens (LMIS)

isolated from the membrane fraction of cells from a breast cancer cell line, with potential immunostimulatory and antineoplastic activities. Upon administration, allogeneic large multivalent immunogen breast cancer vaccine may stimulate a cytotoxic $T$ lymphocyte $(\mathrm{CTL})$ immune response against tumor cells that express the breast cancer cell-specific LMIs. 